\title{
The Impact of Audit Committee Characteristics on Real Earnings Management: The Moderating Role of Seniority Level and Education Level of Chief Financial Officer
}

\author{
Michelle Tevi Goeinawan ${ }^{1, *}$ Micheline Clarissa ${ }^{1}$ Yulius Jogi Christiawan ${ }^{1}$ \\ ${ }^{I}$ Department of Business Accounting, Petra Christian University, Surabaya, Indonesia \\ * Corresponding author. Email:d12180171@john.petra.ac.id
}

\begin{abstract}
The aim study of the Impact of audit committee characteristics, especially at composition of women on real earnings management, has been widely carried out with mixed results. Upper-echelon theory explains that the characteristics of its leaders will influence the company's performance. The achievement of profits reflected the company's performance. To achieve the profit target, companies need the characteristic of the Chief Monetary Officer (CFO). CFOs who has insight, broad experience and good communication skills will be more considerate and careful in carrying out earnings management to strengthen company performance. The characteristics of the company's leadership meant are the level of seniority and education of the CFO. Seniority and training stage of CFO are concept to have an effect on the connection between the characteristic of the audit committee and the real income management of an organization. This study aims to examine whether the stage of CFO seniority and schooling can affect the relationship between audit committee characteristics and real salary management. The researchers conducted the find out about on 351 agencies in all sectors, besides banking, which have been listed on the IDX in 2018-2019. The statistics evaluation used panel records regression the use of Gretl software. The consequences of trying out the data proved that greater women composition in the audit committee would probably make bigger the practice of actual profits management. Furthermore, the expand in actual salary administration due to the extra composition of women on the audit committee will be weaker in businesses with a excessive degree of CFO seniority compared to those with low CFO seniority levels. This learn about failed to show the moderating position of CFO training on the relationship between woman composition in the audit committee with real income management. The researchers anticipate the study consequences are useful for shareholders to pay greater interest to the composition of women in the audit committee, the level of seniority, and the schooling of CFOs to avoid real earnings management practices.
\end{abstract}

Keywords: Audit committee characteristics, Education level, Real earnings management, Seniority level, Upper-echelon theory.

\section{INTRODUCTION}

Earnings management is the act of influencing a company's profit figures carried out by management. Influencing profit figures means increasing or decreasing profits. Companies use profit figures as a decisionmaking tool for external and internal parties such as shareholders, employees, the public, banks, and others where external and internal parties of the company have their respective interests. In achieving these interests, companies need to conduct earnings management actions.

Earnings administration movements have two types; real salary administration and accrual earnings management. The reason of both real earnings administration and accrual earnings administration is to prioritize current revenue pursuits [1]. However, real earnings administration is carried out in the company's day by day activities, while accrual revenue administration is an revenue administration motion related to accounting policies. This study uses actual 
salary management, one of the practices of salary management. The real earnings used in this study because of the shift in earnings management patterns caused by the development of the times [2], and Managers use it more often because it is more difficult to detect by auditors than accrual earnings management [2], [3], [4]. In addition, according to Firmansyah and Irawan [5], accrual earnings management is riskier in managing period-end reports. Therefore, to supervise management in carrying out real earnings management, an audit committee is needed.

The audit committee has a substantial position in conducting supervisory and controlling functions [6]. Therefore, the presence of an audit committee radically affects the business enterprise [7], [8], [9] to supervise the management in doing day by day things to do transparently, open, and responsibly. Previously, there have been many research involving the presence of audit committees, in particular on the composition of women in audit committees and real earnings management. Such as lookup performed by Thiruvadi \& Hua Wei [10], Gavious et al. [11], Setiawan et al. [12], Mardessi \& Fourati [13], who found the outcomes that the composition of ladies in the audit committee affected negatively on accrual revenue management and actual profits management. However, the results of this study are distinct from the lookup carried out by Novilia \& Nugroho [14], Karen \& Oktavia [15], which found that the composition of women in the audit committee did no longer affect revenue management. Because the consequences of previous studies have been mixed, it is suspected that there is a connection with CFO characteristics.

Based on upper-echelon theory, each company needs leadership characteristics to achieve and strengthen company performance [16], one of which is CFO characteristics. From the previous research, no research considers the characteristics of a CFO. The characteristics of the $\mathrm{CFO}$ are the condition of seniority and CFO education. The condition of seniority and CFO education can give a boost to or weaken the relationship between an audit committee and actual salary management. The presumption is that CFOs with a high level of seniority will have extensive experience so that they are more careful in managing earnings than those with a low level of seniority. In contrast, CFOs with a high level of education can use their insights to strengthen company performance. Therefore, this study aims to examine whether seniority and CFO schooling degree can have an effect on the relationship between the composition of women in the audit committee on actual earnings management.

In this research, there is one independent variable, the composition of women on the audit committee; one dependent variable, real earnings management; two moderating variables, seniority level and CFO education; and two control variables, Return On Assets and Leverage.

\section{LITERATURE REVIEW}

This study makes use of business enterprise theory, nature theory, and upper-echelon concept to explain the relationship between the existence of an audit committee, real income management, seniority degree and $\mathrm{CFO}$ training.

\subsection{Agency Theory}

Agency theory is the base for research on the connection between the existence of an management of real earnings management and audit committee. Agency theory is a theory that discusses about agents and principals have their focus and interests. According to Jensen \& Meckling [17], agents and principals are parties who prioritize their interests and maximize their utility. The principal is the owner of the company, which is more focused on ensuring the company's performance and the correctness of the information in the company. At the same time, the agent is the company's management who puts the responsibility on the principal to gain benefits for the principal.

In this concept, agents and principals are rational parties who prioritize their respective interests. The agent must make a profit for the principal, but the agent is interested in making a profit for himself (bonus plan). At the same time, the principal is interested in ensuring the performance and correctness of the information on the company. As a result, the presence of an audit committee is predicted to be capable to supervise management in the implementation of real income management practices..

\subsection{Upper-echelon Theory}

Upper-echelon theory discusses that the leader's characteristics influence the company's performance and management techniques [16]. Characteristics of high leadership can strengthen company performance, such as preventing management from doing earnings management. The leader's characteristics can be seniority level, education level, age, and others. According to Andhara et al. [18], seniority is the length of time a person has worked and affects high positions. Usually, a long work experience can increase a person's position in a company. Someone with vast work experience will get a broader insight into the world of work.

According to Nurkholis [19], education is essential for a person to get perfect development. Because the education of company employees tends to influence them to innovate [20], workers with high education will have accessible opportunities to work. A high level of education might influence company performance and 
company decision making positively. Therefore, the expectation is that CFOs with high levels of seniority and education can influence the connection between audit committee characteristics and real earnings management.

\subsection{Nature Theory}

Nature Theory discusses the differences between women and men to provide different circumstances or implications between the two genders. This difference provides different roles and tasks because of biological factors consisting of genes, chromosomes, nerve cells, brain structures and others. According to Azizah et al. [21], if the theory of nature is associated with companies, it will refer to differences in behaviour and traits between women and men.

\subsection{Real Earnings Management}

Real earnings management is an act of influencing earnings in the company's daily activities in a certain period. According to Roychowdhury [2], management performs real earnings management by paying attention to the company's short-term performance, which causes a long-term decline in value and negatively affects future company performance. Real earnings management is also divided into three measurements; peculiar discretionary expenses, peculiar cash drift operations, and atypical production costs. Real salary administration in this study uses a measurement with a proxy for extraordinary money float operations (Ab_CFO). Ab_CFO is the difference between real cash flow operations (CFOR) and normal cash flow operations (NCFO). If Ab_CFO is positive, the real cash flow operations are more significant than normal cash flow operations. This situation means that there is earnings management in the form of increased profits and vice versa. Therefore, the following formula is obtained:

\section{$A b \_C F O$ it $=$ CFORit-NCFOit}

Description:

CFORit = Cash Flow from operations $/ \mathrm{TA}_{\mathrm{t}-1}$

Furthermore, NCFOit is estimated using the following regression model:

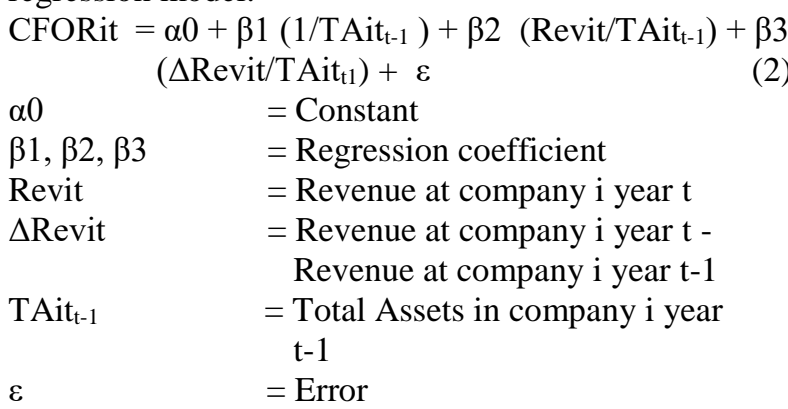

\subsection{Audit Committee}

The audit committee is shaped via the company's board of commissioners and refers to the Financial Services Authority (OJK) Regulations Number 55/POJK.04/2015 regarding the establishment and tips for the implementation of audit committee work. The audit committee shaped by way of the board of commissioners has the responsibilities and duties to oversee the activities of the company's management, make certain compliance with agency policies [22]. In addition, the audit committee is additionally responsible for reviewing the company's monetary data such as the reliability of economic statements so that administration consists of out daily things to do of the organization in a transparent, open and accountable manner. The supervisory function of the audit committee will motivate enterprise administration to control the agency better healthily [6]. The audit committee can be measured by the usage of the characteristics of the audit committee such as age, the composition of guys or girls in the audit committee, size (number) and others. In this study, the characteristics of the audit committee studied were the composition of girls on the audit committee.

\subsection{CFO Characteristics}

The CFO is one of the members of the company's management who is responsible for finance and decision making in the company's operational activities. According to Kurniawan [23], the leader has the challenge of influencing his colleagues to work with the leader to achieve the preferred organizational goals. The CFO has the undertaking of supporting the Chief Executive Officer in solving monetary troubles of spending, budgeting, funding and preparing economic reports. In addition, the CFO contributes to the company's strategy on financial plans, investment composition and aid allocation for choice projects [24].

According to Florackis \& Sainani [25], the individual characteristics of CFOs influence the choice and results of a company's business. There are several things to consider in choosing a CFO, one of which must pay attention to several characteristics such as education, seniority, age, gender, and others. By paying attention to some of the characteristics above, it will support the selection of a CFO with high integrity in realizing the company's achievements and being an example for other employees to imitate the habbit of their superiors. In addition to influencing other workers, CFOs with good characteristics can estimate earnings accurately so that management does not carry out earnings management opportunistically. In this research the characteristics studied were the level of seniority and education of the CFO. 


\subsection{Return On Asset}

Return on Assets (ROA) is one of the profitability ratios. The profitability ratio is a ratio that offers an overview of the company's capacity to earn earnings from organization activities. Furthermore, it also gives an overview of the company's capacity to generate profits regardless of funding [26]. The higher the ROA fee of a enterprise indicates that the organization is greater effective in acquiring income by using utilizing its assets, and vice versa, the decrease the ROA fee of a enterprise shows that the business enterprise is less superb in obtaining profits with the aid of using its assets. This study uses ROA as a manage variable.

\subsection{Leverage}

Leverage is a loan that is used to increase the return on investment. Leverage can be analyzed by comparing total debt to total assets to measure how much loan or debt funds are used to purchase equipment or other assets. Suppose the leverage ratio has a value above 0 . In that case, the company also operates using debt. In contrast, if the leverage ratio has no value or is equal to 0 , then the company does not use debt funds or uses its funds in operating the company. In addition, leverage can increase profits, such as lowering taxes, but leverage that is too large can also harm the company if the company experiences financial problems.

\subsection{The Connection between Audit Committee Characteristics and Real Earnings Management}

According to Al-Hadrami et al. [22], the audit committee is accountable for carrying out the supervisory feature of the company's management things to do so that an audit committee is needed in each and every agency. In agency theory, the company is also directed to involve and have an audit committee to increase supervision of company activities. The audit committee can be seen by using several characteristics, such as the composition of women in the audit committee.

According to Hegelson [27], the differences of social categories between men and women, such as psychological appearance and roles in social life. Based on the theory of nature, differences caused by genetic factors, nerve cells, brain cells, and others owned by men and women will give different circumstances or implications, giving rise to differences in leadership styles. According to Peni \& Vahamaa [28], in addition to differences in leadership styles between men and women, there are also differences in communication skills, conservatism, decision-making, and risk aversion. Based on the previous explanation, the audit committee with a dominant composition of women will encourage earnings management practices in the company. This situation is presumably due to differences in leadership styles between women and men. According to Gibson, male leadership tends to be more assertive and goal-oriented, while female leadership tends to emphasis on the interaction and well-being of subordinates [29].

Furthermore, it is suspected that the appointment of a female audit committee can be known as a fortune [30] regardless of its capabilities so that the oversight carried out by the female audit committee on management is looser and causes management to take actions that benefit themselves. Based on this explanation, the conclusion is that the higher the composition of women in the audit committee, the higher the management's actions to increase profits so that it can be hypothesized as follows:

$\mathrm{H}_{1}$ : The composition of female in the audit committee affects positively real earnings management.

\subsection{CFO Characteristics Relationship with Audit Committee Characteristics and Real Earnings Management}

Based on the upper-echelon theory, the characteristics of the CFO will have an effect on administration in carrying out real salary management. The traits of the CFO encompass the seniority degree and schooling of the CFO. According to Thommes \& Klabuhn [31], he length of a person's working period will have an effect on his work results. They suspect that the seniority degree of CFOs with giant work ride will enhance the company's overall performance because they are extra thoughtful and careful in conducting income administration and can suppress real earnings administration practices. Therefore, the longer the seniority of the CFO can have an effect on the relationship between the existence of the audit committee and real earnings management. A high CFO seniority stage can help female audit committees due to the fact CFOs with high seniority levels will be more careful and rethink each and every motion taken to help audit committees with a woman composition be more assertive in carrying out their duties. Therefore, the conclusion is that the longer the seniority of the CFO, the lower the real revenue administration motion to make bigger income due to the fact of women's composition in a company. Therefore, acquired the following hypothesis:

$\mathrm{H}_{2}$ : CFO seniority level weakens the positive connection between the composition of female in audit committee and real earnings management.

Based on upper-echelon theory, CFO education level is a significant matter to consider in choosing CFO with integrity. The presumption is that $\mathrm{CFO}$ with high education will have broader insight to strengthen the company's performance, conduct supervision, and predict profits correctly. The research results by Ginesti et al. [32] also found that CFO with a high educational background is more likely to give more resources for company activities such as company research and development. Moreover, according to 
Papadakis [33], leaders who have high education can strengthen the company's performance and affect decision-making.

A higher level of CFO education can help the audit committee carry out its duties and responsibilities, especially in real earnings management actions. According to Hans et al. [34], CFOs can be more effective when influenced by a shared understanding of their educational background. This explanation also supports the theory developed by Hambrick \& Mason [16], Hambrick [35], which says that a high level of education will affect the company's strategy and performance to achieve the desired goals. Therefore, the conclusion is that the highest level of the education level of the CFO, the lower the real earnings management action to increase profits because of women's composition in a company. Therefore, obtained the following hypothesis:

$\mathrm{H}_{3}$ : CFO education level weakens the positive connection between the composition of audit committee women and real earnings management.

\section{METHOD}

This researcher conducted the study on 644 companies from all sectors except the banking sector, listed on the Indonesia Stock Exchange for 2018-2019. Purposive sampling is used in this research with the criteria that the company has complete data used to measure real earnings management, ROA, leverage, CFO seniority and education level, and the women audit committee composition during 2018 2019. After sampling with the above criteria, 351 companies met the criteria, so there were 702 data used and processed in this study.

All the data is from the company's annual report. The data used were operating cash flow, inventory, total assets, income, total debt, the composition of women on the audit committee, seniority level and CFO education.

\subsection{Analysis Model}

The researchers tested the hypothesis in this study using the panel data regression method to examine the effect of the independent variable, the composition of women in the audit committee; on the dependent variable, real earnings management; with moderating variables, seniority and CFO education; and control variables, ROA and leverage.

The hypothesis is tested using the following equation :

$$
\begin{aligned}
\mathrm{Ab} \_ \text {CFOit }= & \alpha 1+\beta 1 \mathrm{KwKAit}+\beta 2 \mathrm{SCit}+\beta 3 \mathrm{PCit}+\beta 4 \\
& \text { KwKAit*SCit }+\beta 5 \mathrm{KwKAit} * \text { PCit }+\beta 6 \\
& \text { ROAit }+\beta 7 \text { Levit }+\varepsilon
\end{aligned}
$$

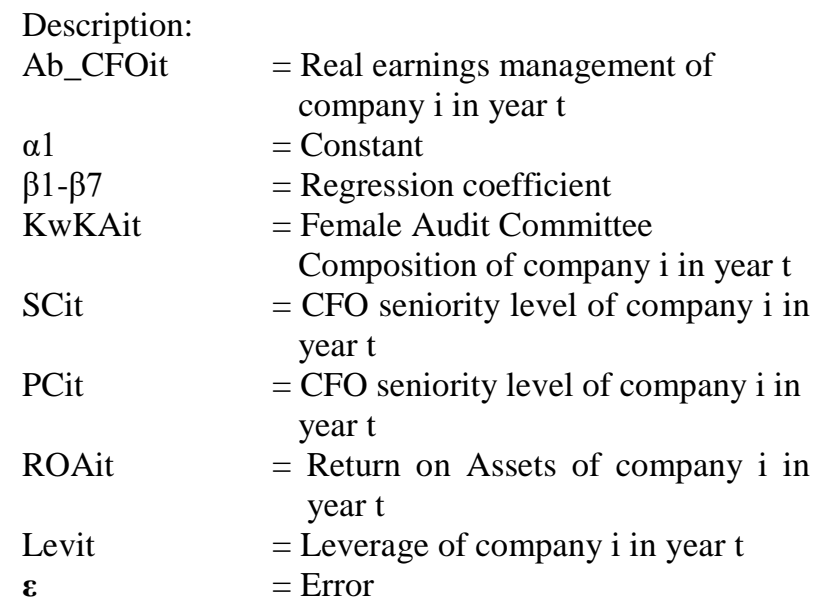

\subsection{Variable Operational Definition}

The following are some explanations of the operational definitions of the variables in this research can be considered in Table 1 .

\section{RESULTS \& DISCUSSION}

The researchers conducted the research on companies listed at the Indonesia Stock Exchange, except for the banking sector, 702 monetary statement data in 20182019. The descriptive statistics of each variable are considered in Table 2.

From Table 2, we can see that the minimal cost on variable KwKA is 0 , the most value is 1 , the average cost is 0.2039 , which capacity that the female audit committee on a business enterprise is $20.39 \%$. The minimum value of ROA is -1.8845 ; the most fee is 0.6072 , the average fee of ROA is 0.0214 , which ability the company's common income is $2.14 \%$ from the complete asset. The minimum price of leverage is 0 , the most price is 4.9010 , the common price is 0.5040 , which skill the average organisation has a debt of $50.4 \%$ from the complete asset.

From Table 2, the study found out from 702 companies in two years; there are 217 CFOs with a level of work experience below or equal to 20 years and as many as 485 CFOs who have work experience level more than 20 years. Furthermore, the study found that 441 CFOs have an education level below or equal to $\mathrm{S} 1$ (Undergraduate degree), and as many as 261 CFOs have an education level above $\mathrm{S} 1$.

This study begins by selecting the diagnostic panel data model, including the Chow test, Hausman test, and Breusch-Pagan test, where the best results show the Fixed Effect Model. Then proceed with heteroscedasticity testing using white's test, and heteroscedasticity occurs. Based on these results, the conclusion is that the best model is the Fixed Effect Model and the presence of heteroscedasticity so that the model is tested by use Weighted Least Squares, and the results attached in Table 3. 
Table 1. Definition of Variable Operational

\begin{tabular}{|c|c|}
\hline Variable & Operational Definition \\
\hline Real Earnings Management (Ab_CFO) & $\begin{array}{l}\text { Real earnings management is measured using one of the proxies developed by } \\
\text { Roychowdhury [2], Abnormal Cash Flow Operations which is calculated by the } \\
\text { equation Ab_CFOit = CFORit - NCFOit }\end{array}$ \\
\hline $\begin{array}{l}\text { Composition of women of the Audit } \\
\text { Committee (KwKA) }\end{array}$ & $\begin{array}{l}\text { The composition of women on the audit committee is measured by the ratio of } \\
\text { women audit committees to the total audit committee }\end{array}$ \\
\hline CFO Characteristics (SC dan PC) & $\begin{array}{l}\text { Seniority (using dummy variable) : } \\
\text { - } 0 \text { = Work Experience <=20 years } \\
\text { - } 1 \text { = Work Experience }>20 \text { years } \\
\text { Education (using dummy variable): } \\
\text { - } 0 \text { = Degree D3-S1 (Undergraduate Degree) } \\
\text { - } 1 \text { = Degree S2-S3 (Graduate Degree) }\end{array}$ \\
\hline Return on Asset (ROA) & Measured using the ratio of income to total assets \\
\hline Leverage (LEV) & Measured using the ratio of total debt to total assets \\
\hline
\end{tabular}

Table 2. Descriptive Statistics

\begin{tabular}{|c|c|c|c|c|c|}
\hline & $\mathrm{N}$ & Mean & Min & Max & St. Dev \\
\hline Ab_CFO & 702 & 0.0000 & -1.2500 & 2.2500 & 0.1672 \\
\hline KwKA & 702 & 0.2039 & 0.0000 & 1.0000 & 0.2533 \\
\hline KwKA*SC & 702 & 0.1290 & 0.0000 & 1.0000 & 0.2198 \\
\hline$K w K A * P C$ & 702 & 0.0688 & 0.0000 & 1.0000 & 0.1673 \\
\hline ROA & 702 & 0.0214 & -1.8845 & 0.6072 & 0.1405 \\
\hline LEV & 702 & 0.5040 & 0.0000 & 4.9010 & 0.4046 \\
\hline \multicolumn{6}{|l|}{ AB_CFO and SC } \\
\hline $\begin{array}{l}0 \text { (work experience }<=20 \\
\text { years) }\end{array}$ & 217 & 0.0092 & -0.4400 & 0.8700 & 0.1281 \\
\hline $\begin{array}{l}1 \text { (work experience > } 20 \\
\text { years) }\end{array}$ & 485 & -0.0040 & -1.2500 & 2.2500 & 0.1820 \\
\hline \multicolumn{6}{|l|}{ AB_CFO dan PC } \\
\hline 0 (Education <=S1) & 441 & -0.0114 & -1.2500 & 0.5900 & 0.1288 \\
\hline 1 (Education > S1) & 261 & 0.0190 & -0.4400 & 2.2500 & 0.2162 \\
\hline
\end{tabular}

Source: Processed Data Results, 2021

Ab_CFO = Abnormal cash flow operation, KwKA = Composition of women of the Audit Committee, KwKA*SC $=$ Moderation of the composition of audit committee women by seniority $\mathrm{CFO}, \mathrm{KwKA} * \mathrm{PC}=$ Moderate composition of audit committee women by education level CFO, ROA = Return on asset, $\mathrm{LEV}=$ Leverage 
Table 3. Weighted Least Squares Analysis Results

\begin{tabular}{|c|c|c|c|c|}
\hline & & Coefficient & P-value & \\
\hline Const & & -0.0352 & 0.0000 & $\star \star \star *$ \\
\hline KwKA & & 0.0741 & 0.0000 & 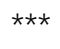 \\
\hline SC & & 0.0140 & 0.0000 & $\star \star \star *$ \\
\hline PC & & 0.0226 & 0.0000 & 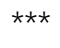 \\
\hline KwKA*SC & & -0.0830 & 0.0000 & $\star \star \star *$ \\
\hline$K w K A * P C$ & & 0.0001 & 0.9953 & \\
\hline ROA & & 0.1829 & 0.0000 & $\star \star \star *$ \\
\hline LEV & & 0.1168 & 0.0157 & ** \\
\hline Adjusted R-squared & $29.91 \%$ & & & \\
\hline P-value & 0.0000 & & & \\
\hline
\end{tabular}

Based on table 3, the adjusted R-square value is $29.91 \%$ which means the composition of the women audit committee (KwKA), CFO seniority level (SC), CFO education level (PC), Return on Assets (ROA), Leverage (LEV) ) has an effect of $29.91 \%$ on real earnings management (Ab_CFO). At the same time, the rest is explained by other independent variables with value of $70.09 \%$, which affects real earnings management. Furthermore, the p-value shows the number 0.0000 , which means that this variable affects real earnings management because the $\mathrm{p}$-value is below 0.05 .

\subsection{Composition of Women in the Audit Committee and Real Earnings Management}

From desk three we can see that p-value of the coefficient of the composition of female in the audit committee is less than 0.05 . These results assist the organisation idea the place the existence of an audit committee has an impact on real revenue management. However the variable composition of women in the audit committee has a fine coefficient of 0.0741 . These effects indicate that the extra female in the audit committee, the greater the abnormal cash float operations or, the more the actual cash flow operations are than everyday money go with the flow operations. Real cash flow operations, which are more significant than normal cash flow operations, indicate management actions to increase profits. This study provided empirical evidence that the more women composition in the audit committee, the lesser strict supervision for management so that management is more daring in increasing profits to benefit themselves. Based on the explanation above, the first speculation regarding the composition of female in the audit committee has a advantageous effect on real earnings management. The consequences of this study are in line with the argument according to Nugrahani \& Yuniarti [36], which says that the nature of women can sometimes miss opportunities that should be able to improve and support company performance. In addition, based on the theory of nature, men and women have differences which also support Gibson's argument that male leadership tends to be more assertive and goaloriented [29] so that management tends not to do real earnings management.

\subsection{Moderating Role of CFO Seniority Level on the Composition of Women in the Audit Committee on Real Earnings Management}

Based on table 3, we can see that the p-value of the CFO seniority variable, which moderates the relationship between the composition of women in the audit committee and real earnings management, is less than 0.05 and has a negative coefficient of -0.0830 . These results indicate that the increase in earnings caused by the increase in the composition of women in the audit committee will be lesser in companies with experienced CFO conditions than in less experienced CFOs. These results support the upper-echelon theory [16] where leaders with good characteristics will strengthen company performance. This situation is because CFOs who have more extended work experience can be more careful and rethink every action they want to take to help women in the audit committee be more assertive in carrying out their duties. Similarly, according to Setiawan [12], the term of office or the length of time a person works is closely related to the company's experience and expertise to reduce earnings management. In addition, according to Han et al. [34], CFOs can be more effective when influenced by shared understanding 
with their tenure in the organization. Based on the explanation above, the second hypothesis regarding the level of CFO seniority weakening the relationship between the composition of women in the audit committee and real earnings management is acceptable.

\subsection{Moderating Role of CFO Education Level on the Composition of Women in the Audit Committee on Real Earnings Management}

The p-value of the CFO education variable is more than 0.05 and has a positive coefficient of 0.00000712 , which moderates the relationship between the composition of women on the audit committee and real earnings management, can be seen in table 3 . These results indicate that the increase in profit caused by the increase in the composition of women in the audit committee is not different in companies with high and low CFO education levels. Then the third hypothesis is rejected. This situation is presumably because many women in the audit committee do not guarantee sufficient expertise. After all, they may be selected due to luck so that even though CFOs accompany them with high and low levels of education, they still do not affect management activities in real earnings management actions.

\section{CONCLUSION}

This study ambitions to examine whether or not the composition of girls in the audit committee impacts actual salary management. This find out about shows that the composition of girls in the audit committee has a tremendous effect on real earnings management, which ability that the higher the composition of female in the audit committee will make administration practice actual income management in the form of increased profits.

In addition to the above objectives, this study additionally ambitions to observe whether or not the degree of seniority and training of CFOs can affect the relationship between the composition of female on the audit committee and actual income management. This find out about suggests that management things to do increase income due to the increasing variety of female in the audit committee, which will be smaller in groups with a high level of CFO seniority. Moreover, the degree of schooling of the CFO does now not have an effect on administration activities, growing earnings due to the growing quantity of ladies in the audit committee.

The results of this learn about are anticipated to be beneficial for shareholders who want to form, reorganize or appoint an audit committee and CFO. This find out about affords proof that the CFO seniority level can have an effect on the composition of ladies in the audit committee on real revenue management so that businesses can be greater cautious in appointing audit committees and CFOs. By paying more interest to this, it is hoped that decision-making will be better, effective, efficient, and gain the company.

This find out about has limitations, it has now not used the banking sector listed on the Indonesia Stock Exchange, the existence of the audit committee only uses the composition of girls in the audit committee, and the size of actual salary management uses only one of three measurements, the ordinary cash drift operations. Further lookup can use all employer sectors with a extra extended yr period, add characteristics other than the audit committee and $\mathrm{CFO}$, and add or replace control and moderating variables.

\section{ACKNOWLEDGMENTS}

We thank God for giving us the smooth process of compiling this journal article. We also thank the supervisory lecturers of Petra Christian University who have guided the work of this journal article. In addition, we are grateful for technological advances that help us and make it easier to work on journal articles. Moreover, we also thank family and friends who have supported in completing this journal article.

\section{REFERENCES}

[1] R. P. Sitanggang, Y. Karbhari, B. T. Matemilola, and M. Ariff., "Audit quality and real earnings management: Evidence from the UK manufacturing sector," Int. J. Manag. Financ., vol. 16, no. 2, pp. 165-181, 2020, doi: https://doi.org/10.1108/IJMF-03-2018-0095.

[2] S. Roychowdhury, "Earnings management through real activities manipulation," Earn. Manag. through real Act. Manip. J. Account. Econ., vol. 42, no. 3, pp. 335-370, 2006, doi: https://doi.org/10.1016/j.jacceco.2006.01.002.

[3] D. Ratmono, "Manajemen Laba dan Berbasis Akrual; Dapatkah auditor yang berkualitas mendeteksinya?," in Simposium Nasional Akuntansi XII, 2010, pp. 1-23.

[4] D. A. Cohen and P. Zarowin, "Accrual-based and real earning management activities around seasoned equity offerings," J. Account. Econ., vol. 50, no. 1, pp. 2-19, 2010, doi: https://doi.org/10.1016/j.jacceco.2010.01.002.

[5] A. Firmansyah and F. Irawan, "Adopsi ifrs, manajemen laba akrual dan manajemen laba riil," J. Akunt. dan Pendidik., vol. 7, no. 2, pp. 81-94, 2018, doi: http://doi.org/10.25273/jap.v7i2.3310.

[6] B. Chrisdianto, "Peran komite audit dalam good corporate governance," J. Akunt. Aktual, vol. 2 no. 1 , pp. 1-8, 2013 
[7] J. J. Forker, "Corporate governance and disclosure quality," Account. Bus. Res., vol. 22, pp. 111-124, 1992.

[8] M. S. Beasley, "An empirical analysis of the relation between the board of director composition and financial statement fraud," Account. Rev., vol. 71, no. 4, pp. 443-465, 1996.

[9] M. W. Ningsih and H. Laksito, "Pengaruh karakteristik komite audit terhadap pengungkapan modal intelektual," Diponegoro J. Account., vol. 3, no. 3, pp. 1-13, 2014.

[10] S. Thiruvadi and H. Hua-Wei, "Audit committee gender differences and earnings management, gender in management," An Int. J., vol. 26, no. 7, pp. 483-498, 2011, doi: https://doi.org/10.1108/17542411111175469.

[11] I. Gavious, E. Segev, and R. Yosef, "Female directors and earnings management in high technology firms," Pacific Account. Rev., vol. 24, no. 1, pp. 4-32, 2012, doi: http://dx.doi.org/10.1108/01140581211221533.

[12] D. Setiawan, "Karakteristik dewan komisaris dan manajemen laba: Bukti pada peristiwa penawaran saham perdana," J. Siasat Bisnis, vol. 22, no. 2, pp. 164-181, 2018, doi: https://doi.org/10.20885/jsb.vol22.iss2.art4.

[13] M. Mardessi, S, M., \& Fourati, Y, "The impact of audit committee on real earnings management: Evidence from Netherlands," Corp. Gov. Sustain. Rev., vol. 4, no. 1, pp. 33-46, 2020, doi: https://doi.org/10.22495/cgsrv4i1p3.

[14] O. Novilia and I. Nugroho, P, "Pengaruh manajemen puncak wanita terhadap manajemen laba," Din. Akuntansi, Keuang. dan Perbank., vol. 5, no. 1, pp. 27-45, 2016.

[15] J. Karen and Oktavia, "Pengaruh karakteristik organ tata kelola perusahaan terhadap praktik manajemen laba," J. Akunt., vol. 19, no. 1, pp. 116, 2019.

[16] D. C. Hambrick and P. A. Mason, "Upper echelons: the organization as a reflection of its top managers," Acad. Manag. Rev., vol. 9, no. 2, pp. 193-206, 1984, doi: https://doi.org/10.2307/258434.

[17] M. C. Jensen and W. Meckling, "Theory of the firm: managerial behavior, agency cost and ownership structure," J. Financ. Econ., vol. 3, no. 4, pp. 305-360, 1976, doi: https://doi.org/10.1016/0304-405X(76)90026-X.

[18] A. S. D., H. N. Utami, and W. Mayowan, "Pengaruh senioritas dan loyalitas terhadap promosi jabatan (studi pada karyawan departemen kebijakan ekonomi dan moneter bank Indonesia Jakarta)," J. Adm. Bisnis, vol. 22, no. 1, pp. 1-9, 2015.

[19] Nurkholis, "Pendidikan dalam upaya memajukan teknologi," J. kependidikan IAIN Purwokerto, vol. 1, no. 1, pp. 22-44, 2013, doi: ttps://doi.org/10.24090/jk.v1i1.530.

[20] G. Sannino, F. Di Carlo, and M. Lucchese, "CEO characteristics and sustainability business model in financial technologies firms," Manag. Decis., vol. 58, no. 8, pp. 1779-1799, 2020, doi: https://doi.org/10.1108/MD-10-2019-1360.

[21] W. Azizah, F. Zoebadi, S. Bantasyam, and Y. R. Oktaviani, "Earnings management in indonesia: are women always under?," IOSR J. Bus. Manag., vol. 21, no. 11, pp. 42-46, 2019.

[22] A. Al-Hadrami, A. Rafiki, and A. Sarea, "The impact of an audit committee's independence and competence on investment decision: A study in Bahrain," Asian J. Account., vol. 5, no. 2, pp. 299-313, 2020, doi: https://doi.org/10.1108/AJAR-02-2020-0008

[23] A. W. Kurniawan, "Pengaruh kepemimpinan dan pengembangan sumber daya manusia terhadap kepuasan kerja, motivasi kerja, dan kinerja karyawan bank Sulselbar," J. Ekon. dan Keuang., vol. 16, no. 4, pp. 391-408, 2012, doi: https://doi.org/10.24034/j25485024.y2012.v16.i 4.119 .

[24] S. Firk, T. Schmidt, and M. Wolff, "CFO Emphasis on value-based management: Performance implications and the challenge of cfo succession," Manag. Account. Res., vol. 44, pp. 26-43, 2019, doi: https://doi.org/10.1016/j.mar.2018.11.001.

[25] C. Florackis and S. Sainani, "How do chief financial officers influence corporate cash policies?," J. Corp. Financ., vol. 52, no. C, pp. 168-191, 2018.

[26] I. G. H. Darmawan and I. M. Sukartha, "Pengaruh penerapan corporate governance, leverage, roa, dan ukuran perusahaan pada penghindaran pajak," E-Jurnal Akunt., vol. 9, no. 1, pp. 143-161, 2014.

[27] V. Hegelson, The psychology of gender 4th ed, 4th ed. America: Pearson Education, 2012.

[28] E. Peni and S. Vahamaa, "Female executives and earnings management," Manag. Financ., vol. 36, no. 7, pp. 629-645, 2010, doi: $10.1108 / 03074351011050343$.

[29] N. Herachwati and B. D. Basuki, "Gaya Kepemimpinan Laki-laki dan Perempuan," Maj. Ekon., vol. 22, no. 2, pp. 135-147, 2012.

[30] D. P. Pertiwi, "Pengaruh Karakteristik komite audit terhadap kualitas laporan keuangan perusahaan non keuangan dengan kualitas audit 
sebagai variabel moderasi," J. Fairness, vol. 9, no. 3, pp. 215-228, 2019.

[31] K. Thommes and J. Klabuhn, "Age and tenure diversity on the work floor: Evidence from a natural field experiment in production," Evidence-based HRM a Glob. Forum Empir. Scholarsh., vol. 9, no. 11, pp. 95-117, 2021, doi: https://doi.org/10.1108/EBHRM-04-2019-0033.

[32] G. Ginesti, R. Spano, L. Ferri, and A. Caldarelli, "The chief financial office (cfo) profile and r\&d investment intensity: Evidence from listed european companies," Manag. Decis., vol. 59, pp. 1-16, 2021, doi: https://doi.org/10.1108/MD05-2020-0650.

[33] V. M. Papadakis, "Do CEOs shape the process of making strategic decisions?: Evidence from Greece," Manag. Decis., vol. 44, no. 3, pp. 367394, 6AD, doi: https://doi.org/10.1108/00251740610656269.

[34] J. Han, J. Zhang, and J. Han, "CFO as a strategic partner of the ceo: Relational demography and firm financial performance," J. Bus. Manag., vol. 21, no. 1, pp. 59-76, 2015.

[35] D. C. Hambrick, "Upper echelons theory: an update.," Acad. Manag. Rev., vol. 32, no. 2, pp. 334-343, 2007.

[36] P. Nugrahani, W and R. Yuniarti, "Pengaruh board gender, dewan komisaris independen, komite audit dan kepemilikan institusional terhadap kinerja keuangan perusahaan (Studi kasus pada perusahaan sub sektor bank yang terdaftar di Bursa Efek Indonesia Periode 20132017)," J. Bisnis, Ekon. dan Sains, vol. 1, no. 1, pp. 59-68, 2021. 